\title{
Perception versus Reality-Determining Business Students' Computer Literacy Skills and Need for Instruction in Information Concepts and Technology
}

\author{
Patricia Wallace \\ The College of New Jersey, \\ Ewing, New Jersey, USA
}

pwallace@tcnj.edu

\author{
Roy B. Clariana \\ Penn State University, \\ Malvern, PA, USA
}

rbc4@gv.psu.edu

\section{Executive Summary}

Many colleges and universities require incoming students to demonstrate a prescribed level of computer proficiency. Currently, many educational institutions offer introductory computer courses to assist students in meeting this requirement. Other institutions are considering eliminating introductory computer courses with the expectation that students will demonstrate adequate computer knowledge through the proficiency examination. This assumes that students have acquired both computer knowledge (concepts) and computer skills (applications) in high school or through other personal experiences. Giving the students the option of taking a computer proficiency exam in lieu of a required course allows students to take other required, elective, or optional courses that will assist them in completing their degree requirements. However, not offering the introductory computer skills course may, likewise, be detrimental to students who would otherwise benefit from the knowledge gained from such a course.

Thus, a study of 140 incoming business freshmen was developed to determine if students had adequate computer knowledge and skills to exempt the introductory computer fundamentals course. Using online testing software, students were tested on both computer skills (Excel) and computer concepts that students are expected to master at the completion of an introductory computer fundamentals course. Overall, the findings revealed that the students' average test scores were 60 percent, which is significantly below passing. This study also found that only 36 percent of the students tested could exempt or "test out" of the course if given that option. Students not able to exempt the course demonstrated a mean gain or improvement of 26 points in the Excel post test and 23 points in the Computer Concepts post test following course instruction. This data indicates that course instruction was effective for students not able to exempt the course and achieved the desired effect of providing meaningful knowledge in information technology con-

Material published as part of this journal, either on-line or in print, is copyrighted by the publisher of the Journal of Information Technology Education. Permission to make digital or paper copy of part or all of these works for personal or classroom use is granted without fee provided that the copies are not made or distributed for profit or commercial advantage AND that copies 1) bear this notice in full and 2) give the full citation on the first page. It is permissible to abstract these works so long as credit is given. To copy in all other cases or to republish or to post on a server or to redistribute to lists requires specific permission and payment of a fee. Contact Editor@JITE.org to request redistribution permission. cepts and skills.

Based on these findings, it was concluded that incoming business students lack the necessary computer knowledge, skills, and abilities to pursue their undergraduate degree programs. It is recommended that freshman business students need an introductory computer course that includes both Information Systems (IS) con- 
cepts and Information Technology (IT) software applications.

Keywords: Computer proficiency, computer-based testing, Information Technology, online testing, computer literacy, business students.

\section{Introduction}

Students enrolled in college today have grown up with technology. In fact, their first experience with computers was, for many students, in kindergarten. Likewise, this generation of college students embraces technology - computers, cell phones, digital cameras, mp3 players, video games, etc. - and use it for everyday tasks. Therefore, the perception that incoming college students, particularly business students, possess adequate computer skills has been made by many college administrators and professors. In fact, many colleges have decided to eliminate computer literacy courses based on this assumption. However, before putting beginning students at risk by eliminating introductory computer fundamentals courses, it seems critical to validate the value of such courses (Lynam, 2003, Pierce, Lloyd, \& Solak, 2001).

This study examines this perception of incoming students by utilizing online computer proficiency testing to determine the computer literacy skills of incoming freshman business students. Freshman business students were given two computer literacy tests to determine their proficiency prior to any course instruction in computers. Scores from these tests were then compared to the scores the same students received after completing a computer literacy course. Findings revealed that colleges and universities need to utilize concrete data before making curriculum decisions to ensure that students can demonstrate computer proficiency for future employment.

\section{Literature Review}

\section{Computer Testing Initiatives}

Institutions of higher education, employers, and placement agencies are trying to determine how to appropriately assess students and potential employees' information technology skills. In fact, the Educational Testing Service (ETS) recently announced a standardized test that was designed to measure the computer literacy skills of college students. ETS officials state that although students come to campus knowing how to use a computer, they are not necessarily prepared to use it for high-tech assignments that employers demand. Students can send emails, download music files, and use instant messaging, but employers and others want to know if students can use a computer as a productivity tool to solve recurring business problems (Young, 2004).

The Performance Testing Council (2004), a consortium of Information Technology (IT) industry leaders including Cisco Systems and Microsoft, has joined forces with the testing industry to sponsor a new organization for the research and promotion of performance testing. The Council promotes the use of hands-on testing to provide accurate and reliable measures of competency for IT job tasks. In addition, the International Computer Driving License (ICDL-US) organization provides certification via testing to validate knowledge in computer proficiency. According to its President, Grant Castle, ICDL certification provides validation that a person has fundamental knowledge in areas such as hardware, software, word processing, spreadsheets, operating systems and other areas. (Moore, 2002)

Thomson Prometrics, a leader in Information Technology assessment and certification, has created an Introduction to Computing test that will evaluate students' knowledge of computer vocabulary, definitions, concepts, and general computer literacy. The test consisting of multiple choice items can be used by colleges and universities as a screening device to determine the appropriate placement of students in college computer courses. (Gaber, 2004) 
In addition, Thomson Learning, Inc.'s current online testing tool known as SAM (Skills Assessment Manager) was designed in association with Microsoft Corporation to test both employees' and students' knowledge of computer software applications in the Microsoft Office suite of applications. When used appropriately, SAM can provide training for computer certification testing, which many employers are now requiring. In addition, the Robinson College of Business at Georgia State University in Atlanta, Georgia, used SAM2000, to test both undergraduate and graduate computer literacy skills. (McDonald, 2004)

\section{Computer Literacy Research}

According to Phillips (2001), the expectation of computer literacy is both a burden and an opportunity. The specific technology installed in any workplace constantly changes in sophistication and function. Even though computers have become easier to use over time, their continually advancing capabilities and the increasing variety of available functions and features result in a consistent need for more training. In addition, Phillips notes that skill requirements change over time for any profession and professional positions in organizations that work extensively with computer technology change almost yearly.

In a study titled, "Showcasing the Skilled Business Graduate," 1500 corporate recruiters were surveyed to determine the types of competencies that are needed in today's business graduates. The study found that corporate recruiters are looking for graduates with specific skill sets. In fact, following the number one ranked skill of communication, computer literacy was ranked as the second most desired skill for potential employees. In addition, the authors found that recruiters wanted concrete evidence of student achievement. (Moody, Stewart, and Bolt-Lee, 2002)

Dickerson (2004) agrees that employees need computer skills and that it is outside the realm of overextended Information Technology (IT) departments to provide training on basic computing skills. In his article titled, "Why Can't Johnny Compute?," he states that in a business world where computers are essential tools, basic computer literacy should evolve into a more general human resource concern, both in hiring new employees and training existing ones. Although office workers should be expected to bring basic levels of computer literacy to work with them, developing those skills is clearly more difficult for some than others.

In a report issued by the Task Force on Workforce Development, which included participants from the AFL-CIO, the Business Roundtable and Harvard University, it found that the nation's employment situation is rapidly approaching the point of diminishing returns. In addition to technical proficiency, companies need employees with "soft" skills, including critical thinking and computer literacy, and the ability to work in a team-based environment. The reality is that many of the individuals applying for jobs don't have the training and skill sets necessary for the technology-driven, high-performance workplaces of today. It will take a concerted, collaborative effort by the government, the business and academic communities, and HR to reverse the trend. Otherwise, the US stands to lose its competitive edge in the global economic arena and suffer a serious decline in its standard of living. (Meisinger, 2004)

\section{Methodology}

\section{Research Participants}

Five sections of Computer Fundamentals consisting of 140 incoming freshman business students were utilized as the sample for this investigation during the 2003 academic year. All students in the five sections, regardless of gender, participated in the testing. To insure consistency in research methodology, all sections were taught by the same professor, in the same classroom and computer lab, using the same instructional delivery and testing procedures. This was done to in- 
sure that differences due to instructor, classroom facilities, computer labs, and testing procedures were not mitigating factors. In addition, the testing methodology used in this study was consistent with standard classroom testing practices for the course, Computer Fundamentals.

\section{Course Content}

Computer Fundamentals was a required computer literacy course required of all freshman business students in the AACSB Business School used in this study. The course emphasized computer concepts and computer spreadsheet software. Due to a curriculum transformation, the Computer Fundamentals course was eliminated in the 2004 academic year based on the assumption that incoming freshman students possess adequate knowledge of computer skills and abilities to complete their undergraduate business education.

Designed to enhance computer literacy, this course covered the fundamental concepts of a computer system, including hardware, software, electronic communications, spreadsheet applications and web development. The course also introduces students to computer operating systems (UNIX and Windows), the Internet, and computer-based mathematical applications using spreadsheet software. By the conclusion of the course, students were expected to be proficient in the following areas:

- Working With System Software

- File Management

- Hard Disk Management

- The Internet

- Electronic Mail

- Electronic Discussion Groups

- Conducting Research using the Internet

- Designing Web Pages

- Creating Mathematical Reports

- Employing Arithmetic, Logical, Statistical, and Financial Operators

- Employing Absolute, Mixed, and Relative Cell References

- Integrating and Linking Worksheets

- Data Management

- Creating Graphics

Thus, course topics included introduction to computers, the internet and World Wide Web, application software, components of the system unit, input, output, storage, operating systems and utility programs, communications and networks, computers and society, security, privacy, and ethics.

Excel topics included creating a worksheet and an embedded chart, formulas, functions, formatting, what-if analysis, charting, and financial and database functions.

\section{Testing Software}

Because the literature review cites research that concludes that companies need employees with "soft" skills, including critical thinking and computer literacy (Meisinger, 2004), as well as software skills (Kinnersley, Mayhew, \& Hinton, 2001), the online testing software for this research study included both testing formats. This coincides with plans by the Educational Testing Service officials to release an online test in 2006 that will measure not only proficiency in using computer software but also information processing skills (Young, 2004). In addition, the Chauncey Group International, a subsidiary of Educational Testing Service (ETS) has recently developed a 100- 
item multiple choice test for Introduction to Computing courses so that colleges and universities can measure incoming students' knowledge of computer concepts. The test will enable students to obtain credit by exam and/or test out of the introductory computing courses and apply the credits towards the completion of another college requirement (Chauncey Group, 2002).

For this research study, a 100-item multiple choice test of Computer literacy concepts was developed and used as the Concepts pre-test. The Exam View Pro3.6 test generator software used in this study was provided by the textbook publisher, Course Technology (a division of Thomson Learning). The Exam View Pro 3.6 software allows instructors to create and print both paper and online tests. Using the ExamView software, the 100-item test was created by the instructor by selecting questions from the test bank. All test items were multiple-choice with four answer alternatives. Both the Concepts pre-test and post-test contained the same questions, although the tests were prepared in two versions (Version A and Version B) with the questions scrambled to differentiate the two versions. In addition, the question scrambling provides an additional level of test security along with the user id and password authorization that was utilized in the computer testing lab. Both the pre- and post-Concepts tests had a time limit of 60 minutes. After 60 minutes, the testing was ended and scored. However, it should be noted, that the majority of students completed the multiple choice test in under 60 minutes. Upon ending the test, the testing software scored the test and gave the students immediate feedback on the number of items answered correctly, expressed as a percent. Using such testing software as part of the methodology of this study provided students with immediate reinforcement of tests results and helped to facilitate learning and retention of material since students are able to compare their correct versus incorrect answer choices at the conclusion of the testing. To maintain test security throughout testing, students were required to log off the computer with no saving or printing of test materials allowed at the conclusion of the test.

The second test, an interactive online computer skills test in Excel was generated by a software package titled, SAM XP (Skills Assessment Manager), available from Course Technology and Thomson Learning. The Skills Assessment Manager or SAM is a web-based testing product that measures users' proficiency in Microsoft Office XP applications. The selection of SAM XP for online computer software testing was made because the questions in the package were validated. In fact, SAM XP was developed primarily as a testing package for corporate America. Successful completion of the SAM tests ensures prospective employers that students can attain the MOUS (Microsoft Office User Specialist) certification required by many employers. Thus, in addition to the ability of SAM to store results in its database, its reliability and validity made it an appropriate testing tool for this research study.

The 70-item online Excel test was prepared in two versions (Version A and Version B) and used for both for pre- and post-Excel tests. The questions were the same in both tests with the exception of the scenario that was selected. In Version A, the scenario was a Travel Agency while in Version B, a Cruise Line. In addition, the questions were scrambled and the testing time, like the Concepts test, was limited to 60 minutes. As in the ExamView testing, no printing or saving of test files was permitted. All access to the tests was by user id and password and specific dates and times were assigned to the testing sessions. Thus, test security and confidentially were built into the testing process.

\section{Findings}

Results of the Computer Concepts pretest, which was administered prior to any course instruction, revealed a mean of 57.6 with a standard deviation of 9.7. Following the course instruction in Computer Concepts, the students' posttest revealed a mean of 78 with a standard deviation of 8.5. Overall, students showed an increase of 21 points as a result of instruction in Computer Concepts. 
Likewise, the results of the Excel pretest, which also was administered prior to any course instruction in Excel, revealed a mean of 59.5. Following course instruction in Excel, the students' posttest revealed a mean of 82.4 with a standard deviation of 8.8. In the Excel testing, students showed an increase of 23 points as a result of course instruction.

As noted by Table 1, the Excel and Concepts pretest means are both below $60 \%$, indicating an unacceptable level of prerequisite knowledge in these areas. After instruction, scores improved by an average of 21 points in Computer Concepts and 23 points in Excel as shown in Table 1.

Table 1: Excel and Concepts Test Results Means and Standard Deviations

\begin{tabular}{|c|c|c|c|c|c|}
\hline & \multicolumn{2}{|c|}{ Excel } & & \multicolumn{2}{c|}{ Concepts } \\
\hline & Pretest & Posttest & & Pretest & Posttest \\
\hline Mean & 59.5 & 82.4 & & 57.6 & 78.0 \\
\hline SD & 12.1 & 8.8 & & 9.7 & 8.5 \\
\hline
\end{tabular}

Examination of pretest to posttest performance (see Figure 1) indicates that students across all initial performance levels benefited from instruction, though the lower performing students benefited more.

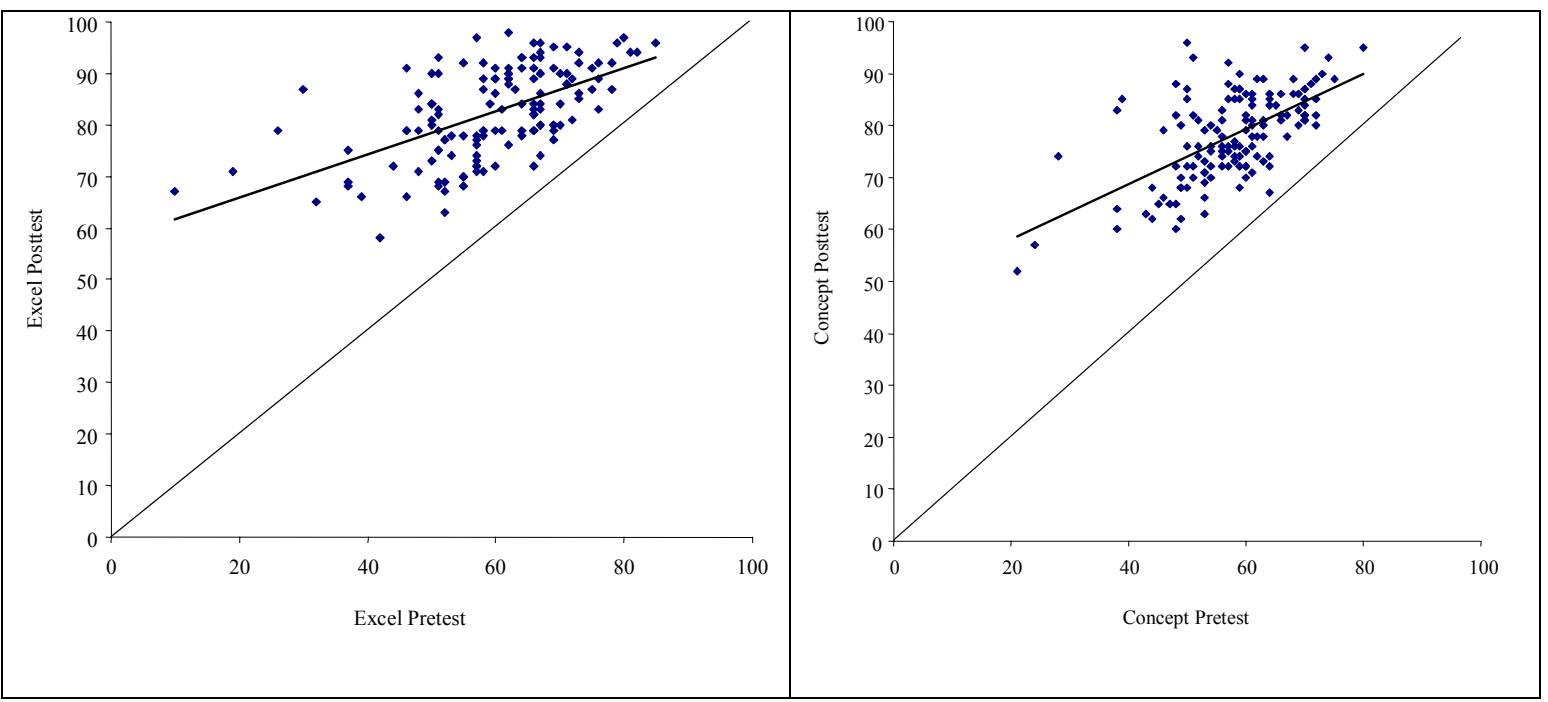

Figure 1: Trend Line Comparison of Pretest and Posttest Performance on the Excel and Concepts Test

Note: The diagonal line would indicate no change from pretest to posttest.

The test data were analyzed as a 2 (Excel test and Concepts test) X 2 (Pretest and Posttest) repeated measures analysis of variance (ANOVA). The posttest scores were significantly greater than the pretest scores and the Excel scores were significantly greater than the concepts scores (see Table 2). 
Table 2: ANOVA Results

\begin{tabular}{|r|r|r|r|r|c|}
\hline \multicolumn{1}{|l|}{ Source } & $\underline{\mathrm{SS}}$ & $\underline{\mathrm{df}}$ & \multicolumn{1}{c|}{$\underline{\mathrm{MS}}$} & $\underline{\mathrm{F}}$ & $\underline{\text { Sig. }}$ \\
\hline PRETEST_POSTTEST & 65931.921 & 1 & 65931.921 & 1157.777 & 0.0000 \\
\hline error & 7972.578 & 140 & 56.946 & & \\
\hline EXCEL_CONCEPTS & 1366.815 & 1 & 1366.815 & 29.327 & 0.0000 \\
\hline error & 6524.684 & 140 & 46.604 & & \\
\hline PRE_POST * EX_CON & 209.815 & 1 & 209.815 & 7.903 & 0.0056 \\
\hline error & 3716.684 & 140 & 26.547 & & \\
\hline
\end{tabular}

The interaction of pretest/posttest and excel/concepts was also significant $(p=0.0056)$. This interaction is shown in Figure 2, indicating that Excel scores increased more from pretest to posttest than did the Concept scores.

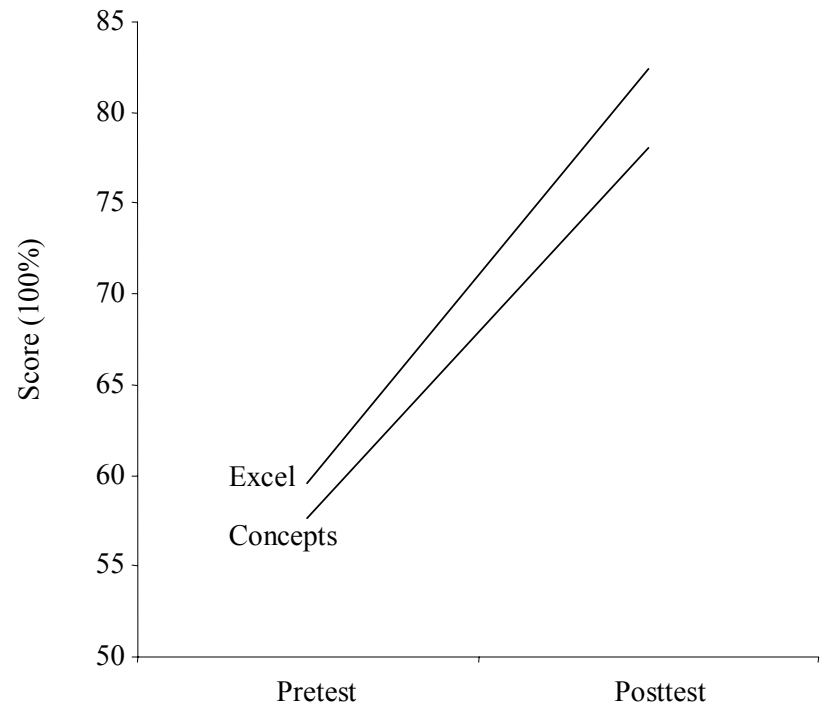

Figure 2: Graph of the Significant Interaction of Excel and Concepts Scores from Pretest to Posttest

As noted in Table 3, the correlation relationships between these tests is also revealing. The Excel and Concepts pretests were most related $(r=.72)$ but were less related after instruction $(r=0.50)$. 
Table 3: Pearson Correlation of Tests

\begin{tabular}{|ccccc|}
\hline & EX & EX & CON & CON \\
& PRE & POST & PRE & POST \\
Excel pretest & 1 & & & \\
Excel Posttest & 0.58 & 1 & & \\
Concepts Pretest & 0.72 & 0.56 & 1 & \\
\cline { 2 - 3 } Concepts posttest & 0.43 & 0.50 & 0.61 & 1 \\
\hline
\end{tabular}

Note: All significance at $p<0.01$

\section{Data Analysis of Students with Below Passing Grades}

Another interpretation of the data can be made by analyzing the student data by removing from the data analysis the students that would have tested out of the course. To test out of the course, a student would have to obtain a score of at least 60 percent on both the Excel and Computer Concepts tests. Therefore, in this study, 64 percent (89 of 140) of the students failed, or scored below 60 percent, one of the two tests. However, the percentage that failed both tests was 39 percent (54 of 140). Consequently, the data from this study revealed that only 36 percent (50 of 140) of the students tested could exempt or "test out" of the course if given that option. Table 4 below reveals the means of the 89 students that obtained below passing scores on one or both tests and, thus, would not be eligible to exempt or "test out" of the course.

Table 4: Means of Students Scoring below 60 Percent $(\mathbf{n}=\mathbf{8 9})$

\begin{tabular}{|c|c|c|}
\hline & Excel & Concepts \\
\hline pretest & 53.8 & 52.6 \\
\hline & $(11.2)$ & $(8.2)$ \\
\hline & & \\
\hline posttest & 79.4 & 75.3 \\
\hline & $(8.7)$ & $(8.6)$ \\
\hline & & \\
\hline gain & $\mathbf{2 5 . 6}$ & $\mathbf{2 2 . 7}$ \\
\hline
\end{tabular}

Of particular note in Table 4 is the mean gain or improvement of 26 points in the Excel post test and 23 points in the Computer Concepts post test of the 89 students. In addition, the data revealed that following instruction, only one student failed the excel posttest and only two students failed the computer concepts posttest. This data indicates that course instruction was effective for the majority of students and achieved the desired effect of providing meaningful knowledge in information technology concepts and skills. 
Finally, Table 5 below, similar to Table 2, shows the ANOVA analysis using only the 89 students that obtained below passing scores on one or both tests and, thus, would not be eligible to exempt or "test out" of the course.

Table 5: ANOVA Results

\begin{tabular}{|r|r|c|r|r|l|}
\hline \multicolumn{1}{|l|}{ Source } & $\underline{\mathrm{SS}}$ & $\underline{\mathrm{df}}$ & $\underline{\mathrm{MS}}$ & $\underline{\mathrm{F}}$ & $\underline{\text { Sig. }}$ \\
\hline PRETEST_POSTTEST & 52131.640 & 1 & 52131.640 & 890.212 & 0.000 \\
\hline error & 5153.360 & 88 & 58.561 & & \\
\hline EXCEL_CONCEPTS & 609.989 & 1 & 609.989 & 10.560 & 0.002 \\
\hline error & 5083.011 & 88 & 57.761 & & \\
\hline PRE_POST * EX_CON & 195.775 & 1 & 195.775 & 5.854 & 0.018 \\
\hline error & 2943.225 & 88 & 33.446 & & \\
\hline
\end{tabular}

\section{Conclusions}

The assumption that incoming freshman business students possess adequate knowledge of both computer concepts and computer literacy skills is not accurate. In fact, the average score of 58 percent on the Concepts pre-test and 60 percent on the Excel pre-test suggests that students do not possess the necessary skills to function in an undergraduate School of Business. Also, in this study, 64 percent of the students failed, or scored below 60 percent in one of the two tests. In addition, the percentage that failed both tests was 39 percent Thus, the data indicates that only about one third of the freshman business students tested could exempt or "test out" of the course if given that option.

It should be pointed out that while some students may eventually pick up some computer skills during the course of their degree program, they would most likely learn them imperfectly and not to the degree that is required by corporate recruiters and potential employers. Finally, based on previous research studies by the authors and other researchers, it is believed that the findings in this study would remain consistent should the assessments and methodology of this study be duplicated. As part of a research program, the authors plan to continue research on the assessment of computer literacy skills of business students in the future.

This study validates a previous study by McDonald of students in the Robinson College of Business at Georgia State University. In that 2004 study, McDonald states that "The College administrators' assumption that the majority of business students have the necessary skills to pursue their undergraduate and graduate degree programs is not warranted."

In addition, the data from this study supports the conclusion that students benefit from instruction in computer concepts and software as noted by the average Excel posttest mean gain of 26 points and the average Computer Concepts posttest mean gain or improvement of 23 points. Therefore, it is concluded that Computer Literacy course instruction is both necessary and effective for freshman business students. Likewise, such instruction provides the desired effect of providing meaningful knowledge in information technology concepts and skills.

Based on the results of the McDonald study, students in the Robinson College of Business are now required to complete a freshman level course that includes both a lecture and lab component. 
Likewise, it is recommended that students in the AACSB School of Business that was part of this study should be required to complete an introductory course in Information Systems and Technology. Currently, several Information Technology courses exist in the transformed curriculum. However, these courses are elective in nature and not required of all incoming business students with the exception of a half-course that currently focuses on Database concepts.

Moreover, it is recommended that a full semester course in Information Technology that includes both computer concepts and computer software (Excel) be required of all incoming business students. This recommendation concurs with other researchers (Moody, Stewart, and Bolt-Lee, 2002) that found that computer literacy is a necessary skill set for business graduates as noted in their study of corporate recruiters. Likewise, McDonald (2004) concluded that "institutions of higher education as well as organizations must provide relevant, structured computer software instruction for students and employees." Dickerson (2004) further notes that in a business world where computers have become essential tools, basic computer literacy should evolve into a more general human resources concern, both in hiring new employees and training existing ones.

Thus, the implication for institutions of higher education, and in particular AACSB Schools of Business, is that the business world expects graduating students to be computer literate. To accomplish this, Schools of Business must provide instruction in both Information Systems (concepts) and Information Technology (software applications).

\section{References}

Chauncey Group. (2002). A unique approach to testing. Retrieved May 14, 2004 from http://www.chauncey.com

Dickerson, C. (2004). Why can't Johnny compute? InfoWorld, 26(41), 24.

Gaber, A. (2004). Conversion: The benefits and best practices of computer-based testing. Retrieved October 10, 2004 from http://www.prometric.com

Kinnersley, N., Mayhew, S., \& Hinton, H. (2001). The design of a web-based computer proficiency examination. Paper presented at the 3lst ASEE/IEEE Frontiers in Education Conference, October, Reno, NV.

Lynam, L. (2003). Required software proficiency in general education and business courses. In McGill (Ed.), Current issues in IT education (pp. 223 - 227). Hershey, PA: IRM Press.

McDonald, D. (2004). Computer literacy skills for computer information systems majors: A case study. Journal of Information Systems Education, 15, 19-34.

Meisinger, S. (2004). Shortage of skilled workers threatens economy. HRMagazine, 49(11), 12.

Moody, J., Stewart, B., \& Bolt-Lee, C. (2002). Showcasing the skilled business graduate: Expanding the tool kit. Business Communication Quarterly, 65(1), 21-37.

Moore, P. (2002). IT skills verification program. Tech Directions, 61(7), 6.

Performance Testing Council. (2004) Industry IT leaders come together to solve certification testing issues. Grass Valley, CA. Retrieved November 15, 2004 from http://www.prnewswire.com

Phillips, J. (2001). Embracing the challenge of leadership. Information Management Journal, 35(3), 58-62.

Pierce, E.M., Lloyd, K.B., \& Solak, J. (2001). Lessons learned from piloting a computer literacy test for placement and remedial decisions. Journal of Information Systems Education, 12(2) 81. Retrieved May 11, 2005 from $\underline{\text { http://www.jise.appstate.edu }}$

Young, J. (2004, November 12). Testing service to unveil an assessment of computer and information literacy. The Chronicle of Higher Education, 51(12), 33. 


\section{Biographies}

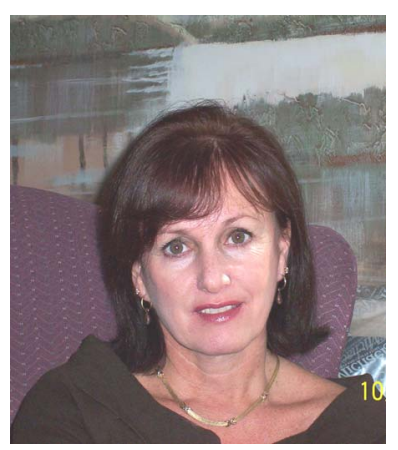

Patricia Wallace teaches courses in Information Systems and Management as an Associate Professor in the School of Business at The College of New Jersey (TCNJ). She earned her doctorate from Temple University and completed post-doctoral study in Management Science and Information Systems at Penn State University.

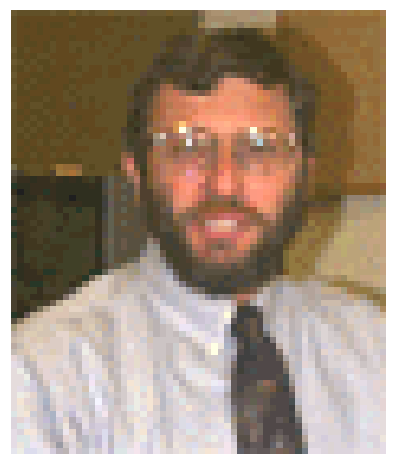

Roy Clariana is an Associate Professor in the Instructional Systems program in the College of Education at the Pennsylvania State University. He earned his doctorate from Memphis State University. 